\title{
VOLODYMYR DERZHAVYN AND THE ARTISTIC UKRAINIAN MOVEMENT
}

\author{
STEPAN KHOROB
}

\begin{abstract}
One of the most productive periods in the career of an outstanding emigration literary theorist Volodymyr Derzhavyn (1899-1964) was the time of his membership in the MUR (Mystetskyi ukrainskyi rukh - the Artistic Ukrainian Movement) in Bavaria, Germany from the mid to the end of the 1940s. The article highlights his theoretical debates with Yurii Sherekh (Shevelov) over the issue of style in Ukrainian diaspora literature.
\end{abstract}

Keywords: MUR, Ukrainian diaspora literature, Volodymyr Derzhavyn, Neoclassicism, nationalorganic style.

The literary activity of Volodymyr Derzhavyn (1899-1964), a renowned literary scholar and critic of the Ukrainian diaspora, has recently become a focal point for the national literary studies. A number of works by both the diaspora and the continental researchers are the evidence of this fact: Volodymyr Derzhavyn - teoretyk neokliasynyzmu (Volodymyr Derzhavyn, the Theorist of Neoclassicism) (1993) by Igor Kaczurowskyj, Povernennia Volodymyra Derzhavyna (The Return of Volodymyr Derzhavyn) (2005) by Taras Salyha, Naukovyi universum Volodymyra Derzhavyna (Volodymyr Derzhavyn's Scientific Summa Rerum) (2005) by Stepan Khorob, Apokryfy Volodymyra Derzhavyna (The Apocrypha by Volodymyr Derzhavyn) (2008) by Oleksandr Astafiev, Volodymyr Derzhavyn: teoriia i krytyka perekladu (Volodymyr Derzhavyn: Translation Theory and Criticism) (2009) by Taras Shmiher, Literaturoznavchi kontseptsii Volodymyra Derzhavyna: dyskussiia z Yuriiem Sherekhom (Volodymyr Derzhavyn's Literary Concepts: the Discussion with Yurii Sherekh) (2007) by Nadiia Basenko, Volodymyr Derzhavyn: mizh indyvidualnoiu pravdoiu $i$ kolektyonymy naklepamy (Volodymyr Derzhavyn: Between the Personal Truth and Collective Slander) (2015) by Yevhen Baran. Most of these researchers analyze the first Ukrainian publication of the selected works by Volodymyr Derzhavyn (Literatura $i$ literaturoznavstvo (Literature and Literary Criticism). IvanoFrankivsk, 2005; U zadzerkalli khudozhnoho slova (Through the Looking Glass of the Literary Word), Vol. 1, Vol. 2. Ivano-Frankivsk, 2012), all the articles - each in its own way - contribute to our understanding of the emigrant researcher - a literary historian and theorist, a linguist and translator.

Volodymyr Derzhavyn's literary legacy (about two thousand research works, most of which are new to the general reader and literary critics) should be systematically analyzed and closely studied (a) in the context of the author's activity and (b) as part of the general literary process in Ukraine (the 1920s-1930s) and in the Ukrainian diaspora (the 1940s-1960s). The scholar's legacy and the methods he employed in his literary-critical works of different genres (articles, reviews, surveys, studies, polemical 
notes, creative portraits, literary essays, and others) should be carefully, analytically considered, and many objective and subjective factors should be taken into account.

Volodymyr Derzhavyn actively participated in the literary and artistic life of that period, especially during his compelled emigration; in his scientific works, he addressed a whole array of issues concerning artistic processes. The researchers of Ukrainian diaspora literary criticism $(\mathrm{H}$. Hrabovych, S. Pavlychko, M. Ilnytskyi, T. Salyha, O. Astafiev, and others) even believe that those processes resulted in the emergence of a specific 'emigration art model', of Volodymyr Derzhavyn in particular. The idea seems to be quite reasonable because the problems highlighted in the scholar's early $20^{\text {th }}$ century works significantly differ from those discussed by him while in emigration (Augsburg, Munich). It was in Germany that he became one of the most prolific critics, a careful researcher of Ukrainian diaspora literature, an influential figure in the fields of art and education; Volodymyr Derzhavyn - together with Yurii Shevelov (Yurii Sherekh), Yurii Boiko-Blokhin, Ivan Koshelivets, Ostap Hrytsai and other diaspora scholars - contributed to the European philological science.

Of special interest is Volodymyr Derzhavyn's work from the mid to the late 1940s related to the Artistic Ukrainian Movement (Mystetskyi ukrainskyi rukh, abbreviated as MUR). Within that period, the scholar produced and published about a hundred literary researches on various themes and problems. Only a few of his major historical/literary papers are named here: Try roky literaturnoho zhyttia na emihratsii (The Three Years of the Literary Life in Emigration), Poeziia Mykoly Zerova i ukrainskyi kliasytsyzm (The Poetry of Mykola Zerov and Ukrainian Classicism), 'Popil imperii' Yuriia Klena i novitnia sproba pereotsinky yoho poezii ('The Ashes of Empires' by Yurii Klen and the Latest Attempt to Reassess His Poetry), Liryka Yevhena Pluzhnyka (Yevhen Pluzhnyk's Lyrics), Poet epokhy (Yevhen Malaniuk) (The Poet of the Epoch (Yevhen Malaniuk)) and others; the main theoretical and methodological studies should also be named: Krystalizatsiia literaturnykh rozbizhnostei (Crystallization of Literary Differences), Problema kliasytsyzmu ta systematyka literaturnykh styliv (The Problem of Classicism and the Taxonomy of Literary Styles), Literaturna krytyka i literaturni zhanry (Literary Criticism and Literary Genres), Problemy styliv i pluzhanstvo za kordonom (The Problems of Styles and Pluzhanstvo* Abroad) and others. Volodymyr Derzhavyn's numerous studies in world literature, linguistics, translation theory are of no less importance.

I will not discuss the genesis of the MUR, its activity and role in the artistic and literary life of the Ukrainian diaspora and the Ukrainian emigrants classified as 'displaced persons' (so-called DPs); there are many studies into these issues both in the diaspora and in Ukraine; this period is justly called the 'Minor Renaissance' and is directly and indirectly related to the period of the 1920s in Ukraine. It will be enough to mention that Volodymyr Derzhavyn's works and speeches generated discussions and debates at the MUR's Congresses facilitating the literary, artistic, and cultural processes in the diaspora. S. Pavlychko rightly states that 'the MUR was not only the organization or the literary epoch. In the context [of time], the MUR is discourse; it is more than the formal organization, more than its official organ, more even than the camps. Some authors (Dmytro Dontsov, for instance) sent their materials to the camp press from abroad, and some important texts - for example, Sherekh's speech at the $3^{\text {rd }}$ Congress - were published in the Hoвi dнi (Novi Dni), Toronto. Besides, using rhetorical patterns of the previous literary periods and extending into the texts of the later times, this discourse goes beyond the chronological boundaries of the institution [1, p. 278-279] $]^{* *}$. This was the MUR supported by Volodymyr Derzhavyn, though he did not agree with (and even rejected) some of its regulations.

The key issues discussed at the MUR's Congresses, conferences, and in its press was its theoretical platform; it determined the policy of the organization, and at first, almost all the members of the MUR approved of the stated principles. As it turned out later, a serious conflict had been laid in the MUR's initial documents produced by its founders; neither Yurii Sherekh nor Volodymyr Derzhavyn nor any other representative of the organization could ignore it: it mostly concerned the principles that determined the development of the literary processes in the Ukrainian community; in the materials, the

\footnotetext{
* Pluzhanstvo (derived from pluh (Ukrainian) - a plough) - thematic, cultural, and artistic primitivism in literature; confining literary quest to rural themes.

** All quotations are translated from the original Ukrainian sources.
} 
old dilemmas of the national literature (presented in a new form - yet contentious) were quite obvious. The main one was the problem of preserving Ukrainian literature in the diaspora context and developing it in accordance with the European tendencies, or, plainly speaking, the problem of the target readers and an appropriate style. For many members of the organization and the initiative committee in particular (Ivan Bahrianyi, Ulas Samchuk, Yurii Sherekh, Volodymyr Derzhavyn, Ostap Hrytsai, Yurii Boiko), the national literature seemed to end up with the absolute indefiniteness of the early 1930s; for them, 'Soviet literature' ceased to exist as an ideological and aesthetic phenomenon. Emigration literature had to enter a new phase of its development. What would it be like, in what direction would Ukrainian literature develop, how could the desired artistry be achieved, how to preserve and enrich the authenticity of the national writing, how to combine it with the European achievements? Those were the most important issues. Even the theoretical slogans and manifestoes issued by the leaders of the organization could not cover up their perplexity, certain indefiniteness that now and then showed itself in their articles and discussions at the MUR's Congresses and conferences.

At first glance, the declaration of the initiative committee of the Artistic Ukrainian Movement was quite clear and comprehensible; it consisted of two postulates:

I. 'The times have placed and place before Ukrainian art that task to which it has been called: to serve the Ukrainian nation by its highly artistic and superb form and in such a way as to establish for itself a voice and an authority in the art of the world'.

II. 'Discarding all that is artistically imperfect and ideologically hostile to the Ukrainian nation, Ukrainian artists are uniting in order to strive in friendly cooperation toward the summit of real and serious art. This union of Ukrainian artists in emigration is open to those masters of the word and brush who write on their flag the motto of an art that is superb, ideologically and formally mature, as well as in a state of constant, eternal quest' $[6$, p. 224]; [2, p. 3].

These principles were presented in the introduction to the first and the main theoretical publication of the MUR under the eloquent title What We Want; they were further developed in the later materials produced by the other members of the initiative committee - Ulas Samchuk, Yurii Kosach, Ostap Hrytsai, Ivan Bahrianyi, V. Petrov (V. Ber, V. Domontovych), and, of course, Yurii Sherekh and Volodymyr Derzhavyn. The latter two started a heated debate over the issues of style in the new Ukrainian literature that led to disagreement concerning the direction in which Ukrainian diaspora literature should move if it wants to be regarded as 'great literature'. It has been mentioned above that at first the declared course of development of the national literature was greeted almost unanimously; it was later that the controversy between Yurii Sherekh and Volodymyr Derzhavyn, who was supported by some other members of the MUR, caused a split in the ranks of the organization, which finally led to its dissolution.

From the very beginning of the MUR's activity, Yurii Sherekh was convincingly arguing in his articles, speeches, and professional discussions that there was no alternative to modernization of the contemporary Ukrainian literature. In his opinion, the process has to be initiated by such authors as Valerian Pidmohylny, Mykola Zerov, Yurii Klen, Pavlo Fylypovych, Mykhailo Drai-Khmara, and other prosaists and poets. According to Solomiia Pavlychko, 'the literature generated by the 1920s Renaissance period secured the foundation upon which to build a new image and a new notion of Ukraine as a European, not just an ethnographic nation. This literature had to exemplify the nationalorganic style; and the members of the MUR were called to develop it in their works!' [1, p. 289]. No one except Yurii Sherekh could explain the criteria and principles of the national-organic style. And it looked as if the originator of the notion had a vague idea about it too. He analyzed the trends and styles of mostly Ukrainian emigration literature - consciously or unconsciously ignoring other layers of the national literature, those represented by the works of the 'Socialist Realism' epoch. Thus it can be inferred that there were almost as many interpretations of the national-organic style as there were members of the MUR. Finally, Yurii Sherekh systematized this diversity of styles; he singled out two dominant trends - 'Europeists' and 'organicists'. According to him, the former was represented by Yurii Kosach, V. Domontovych, Ihor Kostetskyi, and even Ivan Bahrianyi with his overtly contemptuous 'no Europes!'. This trend had to be gradually overwhelmed by other trends and 
tendencies. Yurii Sherekh was convinced that the organic style would eventually gain the dominant position in Ukrainian literature. In his opinion, Vasyl Barka and Todos Osmachka were the brightest representatives of the organic style; there were other diaspora prosaists, poets, and playwrights who followed it, though not all were equally talented. Yurii Sherekh did not seem to ask himself a question whether there was any prospect for the 'organicists', whether they would have a chance to blossom into fully fledged authors in the 'old' and 'rotten' Europe - he did not entertain such doubts.

Probably, this confidence (or overconfidence) was the result of his belief in his own ideological and aesthetic model of the national-organic style; according to Yurii Sherekh, it 'will evolve from the mastered and rejected - because it will be overwhelmed - neoclassical tradition; it [the national-organic style] will come from the passion of the human heart of the epoch of historical cataclysms; it will rest on the deeply rooted national idea expressed in folklore, in the works by Shevchenko. In Shevchenko's works, first and foremost, because Shevchenko has already absorbed and comprehended Ukrainian folklore. The denial of Neoclassicism will be fruitful only if it rests on Shevchenko's tradition' [3, p. 213]. Yet Yurii Sherekh never provided any explanations concerning Shevchenko's tradition in literature and in poetry in particular. He just formulated the general idea - in terms of experimentality, syntheticity, revealing 'the truth of the heart'; no close analysis was ever made.

Interestingly, the researcher pointed out the works of three 'Neo-Expressionists' and 'NeoShevchenkoists', the leading (or prospective) representatives of this national-organic style, who were devoted to its ideological and aesthetic ideals.

As it is rightly stated by Solomiia Pavlychko, his conclusions proved to be so 'general that they cannot be even called recommendations'. Rather, they were proclamation, kind of calls 'in the spirit of those favoured by Mykola Khvylovy':

a) from the general to the national. Not in order to move away from what is common to all humanity; on the contrary, in order to ever more powerfully proclaim and stress it - but to do it in our own, Ukrainian way. The task is not to mimic the things which are common to all humanity, but to enrich the universal experience of all humankind. This is the first pointer. Here the names of Shevchenko and Gogol appear in a new light - it is in them that the modern epoch seeks support;

b) from attempts to grasp the universal, the eternal, the rational to the desire to open your heart, to express your pains, to scream out your screams. From the harmony of Neoclassicism to the artistic chaos of Neo-Expressionism, to what once was somewhat pretentiously called the passionate school' [3, p. 223].

Later, Yurii Sherekh reviewed and rethought his concept of style and the principle of 'national organicity', in Ukrainian emigration literature in particular; he dubbed it 'naive contemplation' and 'expressive daydreaming'. Eventually, the national-organic style, as well as the previously proclaimed idea of 'great literature', proved to be nothing more than a regular episode (it mattered little that it was documented) in the history of the diaspora literary process, an aesthetic phenomenon that had no future because of its indefinite and abstract nature. Still, it aroused opposition within the MUR.

One of the most active and consistent opponents of Yurii Sherekh's concept was Volodymyr Derzhavyn. In his works The Three Years of the Literary Life in Emigration, The Problems of Styles and Pluzhanstvo Abroad, Crystallization of Literary Differences, The Poetry of Mykola Zerov and Ukrainian Classicism, The Problem of Classicism and the Taxonomy of Literary Styles, and in some others, he sharply criticized the very term - the 'national-organic style' - and the semantically related notions ('active romanticism', 'atomic epoch realism'), as well as the artistic essence of the style as it was presented by Yurii Sherekh. Volodymyr Derzhavyn insisted that those definitions were far-fetched, phantom rather than real; it was not what Ukrainian diaspora literature was, nor what it needed [4, p.5].

First of all, Volodymyr Derzhavyn denied Yurii Sherekh's methodological approach in defining the 'national-organic style', as in the latter's works and speeches, there were no explanations that would 'shed light' on the essence of this phenomenon as a unique pattern of the author's ideological and aesthetic consciousness; neither had Yurii Sherekh established any criteria according to which the 'national-organic style' could be compared or correlated with Classicism, Romanticism, the Baroque style, or any other style [4, p.12]. In his other works, for example in Yevhen Pluzhnyk's Lyrics, The Poet of 
the Epoch (Yevhen Malaniuk) and in his later theoretical and methodological study Natsionalna literatura yak mystetstvo (Mystetska meta i metoda natsionalnoi literatury) (The National Literature as Art (The Artistic Goal and the Method of the National Literature)), Volodymyr Derzhavyn utterly rejected Yurii Sherekh's idea of reducing the national literary and artistic diversity to one (dominant) style. Having analyzed the neoclassicism of Mykola Zerov, Yurii Klen, Mykhailo Drai-Khmara, the symbolism of Todos Osmachka, Yevhen Malaniuk, the works by other authors, Volodymyr Derzhavyn came to a definite conclusion. In the critic's opinion, the national literature would not benefit by it; the national ideal could be fully expressed through a variety of styles, each one having its own historical conditionality, ideological and cultural orientation, image and genre structure, aesthetic ideals, etc. According to the scholar, the 'national-organic style' as a new form of artistic thinking is involuntarily presented as superior to the other patterns of style, thus bringing confusion to the criteria for defining the notion of style.

Volodymyr Derzhavyn did not agree with Yurii Sherekh's claim 'that an unsettled life in emigration has to bring about emotional and spiritual rifts and consequently the expressionistic mode of artistic representation'. Moreover, he considered such a view anticultural, destructive, harmful to the development of Ukrainian literature in the context of emigration. Yurii Sherekh did not deny that such views 'were based on the past aesthetic experience' [5, p. 211]. Evidently, Volodymyr Derzhavyn knew it and debunked the idea of 'modernization' of Ukrainian emigration literature. Neither could he ignore Yurii Sherekh's statement that the style paradigm of Neoclassicism had exhausted its creative potential, and that evidence of this fact was the termination of artistic activity of the 'Five-fold Cluster' of the Ukrainian Neoclassicists. In his work The Three Years of the Literary Life in Emigration, Volodymyr Derzhavyn stated that the emigration poetry of the interwar generation proved the viability of Neoclassicism [4, p. 24]; moreover, Neoclassicism stimulated the poetic activity of the 'Prague School' Yevhen Malaniuk, Olena Teliha, Oleh Olzhych, and others. In the post-war period, Neoclassicism rose to its full potential in the poetry of Mykhailo Orest and Yurii Klen. At least, Volodymyr Derzhavyn states so in his studies Lytsar idealu (Mykhailo Orest) (The Knight of the Ideal (Mykhailo Orest)), Poeziia Mykhaila Oresta i neoklasytsyzm (The Poetry of Mykhailo Orest and Neoclassicism), 'Popil imperii' Yuriia Klena $i$ novitnia sproba pereotsinky yoho poezii ('The Ashes of Empires' by Yurii Klen and the Latest Attempt to Reassess His Poetry).

These studies are of historical and literary, theoretical and methodological nature; and here style is regarded not as a decorative feature of a literary work, but as aesthetic comprehension and presentation of human life through systems of artistic images, as an unshakable law of the word's aesthetic transformation in the lyric, epos, and drama. Evidently, this approach to the matter of style presented in Volodymyr Derzhavyn's booklet of the MUR period The Three Years of the Literary Life in Emigration was prepared by his previous studies The Problems of Styles and Pluzhanstvo Abroad and The Problem of Classicism and the Taxonomy of Literary Styles, in which he addressed the issues of macro- and microanalysis of style. In these works of Volodymyr Derzhavyn (as well as in Yurii Sherekh's studies), the problem is (a) analyzed from general theoretical perspective and (b) considered from historical and literary points of view; such a complex approach could potentially help to solve the major problem of Ukrainian emigration literature, especially of the MUR period. Having studied the works of the diaspora authors produced in 1947 (the works of different types and genres, both true ideological and artistic phenomena and mediocre pieces of writing, which were of little effect in the artistic and literary life of Ukrainian emigration, in Germany in particular), Volodymyr Derzhavyn concluded that the aesthetic organization of the word in a given style was the criterion for defining the artistic quality of the style.

It should also be mentioned that unlike Yurii Sherekh, his opponent made it a fundamental principle of his theoretical interpretation of style. Though Volodymyr Derzhavyn failed to create any firm theoretical basis for the Neoclassical style he was promoting, pretty much as Yurii Sherekh failed to provide the foundation for the 'national-organic style'. Each one rejected the other's concept and recognized the priority of one style. According to Mykola Ilnytskyi, 'Volodymyr Derzhavyn - an adherent of Neoclassicism - was apt to label neoclassical anything that had the form of a clear canonical 
verse. Though a closer look at each of the poets mentioned above [Yurii Klen, Todos Osmachka, Maksym Rylsky] shows that Yevhen Malaniuk breaks not only the old "iron" stanza - his voice breaks too as he is looking beyond the edge of being; that M. Orest is a symbolist who deciphers the cryptic writings of the book of forest rather than a Neoclassicist; that in the poem The Poet and in the story Starshyi boiaryn (The Senior Lord), T. Osmachka creates his own myth of Ukraine against the backdrop of the world and even cosmic cataclysms; Yurii Klen may be an exception - he departs from the romantic plots of his collection Karavely (Caravels) (1937) with its adventurous explorers of new lands and comes to the deep equilibrium of historiosophical issues, whose importance he grasps witnessing the clashes between the world forces of evil and justice, light and darkness' [4, p. 212].

Despite the difference in Yurii Sherekh's and Volodymyr Derzhavyn's views, their uncompromising positions concerning the 'national-organic style' and 'Neoclassicism' in Ukrainian emigration literature that aspired to Europeanization, Mykola Ilnytskyi, Igor Kaczurowskyj, and Solomiia Pavlychko pointed out similar tendencies in their approaches. First, both styles were based on the previous aesthetic experience, not on the contemporary artistic practice; second, each scholar absolutized his own artistic intention and rejected any alternative manifestation of style; third, for both of them, the achievements of the national literature (as the basis for the development of the new style) overshadowed the traditions and tendencies of European literatures; fourth, neither of the theorists provided any convincing theoretical and methodological framework for their aesthetics.

Yurii Sherekh and Volodymyr Derzhavyn criticized each other, but neither succeeded in devising coherent strategies for the development of the 'national-organic' or the 'Neoclassical' style, though both of them intended to do it, each in his own way. Yet for both scholars the MUR period was most productive in what concerns literary, artistic, and cultural ideas and, at the same time, most difficult in what concerns presentation of their artistic theories and views, which could supposedly help Ukrainian emigration literature become part of the European literary process. I partially agree with Solomiia Pavlychko's statement that the Volodymyr Derzhavyn of the MUR period was so intricately chaotic and inconsistent in his views that notwithstanding his prolific activity and the amount of papers produced, he was not destined to take the place of the first theorist in the field of the contemporary Ukrainian literature or the MUR' [1, p. 300].

This statement of a well-known researcher is perhaps too strong, and it is subjective to a degree. Volodymyr Derzhavyn's work inspired the other members of the MUR organization and made the contemporary literary, artistic, and cultural life of the many Ukrainian diaspora communities in Germany more dynamic.

\section{REFERENCES}

[1] Павличко С. Модернізація у контексті мистецького українського руху. В: Павдичко С. Теорія літератури. Видавництво Соломії Павдичко “Основи”, К., 2002, 277-381.

[Pavlychko S. Modernizatsiia u konteksti mystetskoho ukrainskoho rukhu. In: Pavlychko S. Teoriia literatury. Vydavnytstvo Solomii Pavlychko "Osnovy", K., 2002, 277-381.]

[2] МУР. Збірник 1. Карлсфельд, Мюнхен; 1946.

[MUR. Zbirnyk 1. Karlsfeld, Miunkhen; 1946.]

[3] Шерех Ю. Не для дітей. Нью-Йорк, 1964.

[Sherekh Yu. Ne dlia ditei. Niu-York, 1964.]

[4] Державин В. Три роки літературного життя та еміграції 1945-1947. Мюнхен, 1948.

[Derzhavyn V. Try roky literaturnoho zhyttia ta emihratsii 1945-1947. Miunkhen, 1948.]

[5] Ільницький М. Мале літературне відродження / Пітературна критика періоду МУРу. В: Ільницький М. У фокусі віддзеркалень: Статті, портрети, спогади. Аьвів, 2005, 202-221. 
[Ilnytskyi M. Male literaturne vidrodzhennia / Literaturna krytyka periodu MURu. In: Ilnytskyi M. U fokusi viddzerkalen: Statti, portrety, spohady. Lviv, 2005, 202-221.]

[6] Isajiw W., Boshyk Yu., Senkus R. The Refugee Experience: Ukrainian Displaced Persons After World War II. Canadian Institute of Ukrainian Studies, University of Alberta, 1992.

Address: Stepan Khorob, Vasyl Stefanyk Precarpathian National University, 57, Shevchenko Str., IvanoFrankivsk, 76025, Ukraine.

E-mail: kaf.lit@ukr.net.

Received: 25.07.2017; revised: 28.09.2017.

Хороб Степан. Творчість Володимира Державина періоду мистецького українського руху. Журнал Прикарпатського університету імені Василя Стефаника, 4 (2) (2017), 63-69.

У статті досліджено творчість українського еміграційного літературознавця Володимира Державина (1899-1964), зв'язану з періодом мистецького українського руху (МУР), котрий тривав 3 середини до кінця 40-х років минулого століття на землі німецької Баварії. Доведено, що цей відрізок часу був чи не найпліднішим для українського теоретика та історика літератури, який брав активну участь у діяльності МУРу. Надто ж це торкається його дискусій з Юрієм Шерехом (Шевельовим) про розвиток стилю в художній дітературі української діаспори.

Ключові слова: МУР, література української діаспори, Володимир Державин, неокласицизм, національно-органічний стиль. 